\title{
The relation of PON1-L55M gene polymorphism and clinical manifestation of Behcet's disease
}

\author{
Ahmet Dursun ${ }^{1 凶}$, Salih Cicek¹, Fatih M. Keni² ${ }^{2}$ Sevim Karakas-Celik1, Tuna Sezer ${ }^{3}$ and Cevdet \\ H. Altinyazar ${ }^{4}$
}

'Bulent Ecevit University, Medical Faculty, Medical Genetics Dept., Zonguldak, Turkey; 2lstanbul Training and Research Hospital, Medical Genetics Department, Istanbul, Turkey; ${ }^{3}$ Bulent Ecevit University, Medical Faculty, Dermatology Department, Zonguldak, Turkey; ${ }^{4 S e l c u k}$ University, Selcuklu Medical Faculty, Dermatology Department, Konya, Turkey

Purpose: Behçet's disease is a multisystem disease characterized by recurrent oral and genital ulcers, relapsing uveitis, mucocutaneous, articular, gastrointestinal, neurologic, and vascular manifestations. Paraoxonase is believed to play an important role in protection of LDL and HDL particles from oxidation, in antioxidant effect against lipid peroxidation on cellular membranes, and in anti-inflammatory process. Lipid peroxidation and free oxygen radicals have been thought to play a role in pathogenesis of BD. The association of paraoxonase gene polymorphisms with Behçet's Disease in a group of Turkish patients with clinical manifestations and healthy controls has been investigated. Patients and Methods: Paraoxonase (PON-1-L55M) gene polymorphism was investigated in 50 Behcet patients and 50 healthy individuals with a PCR/RFLP method. Results: There were significant differences between patients and the control group in allele frequencies of the PON1 L55M polymorphism $(p=0.04)$. Also, when patients were compared with the control group according to clinical manifestations, this statistical significance was getting sharper. Compared with the PON55 L allele, the $\mathrm{M}$ allele was associated with greater than 3.5 fold (OR 3.5, 95\% Cl 1.3-8.9) increased risk of ocular (OR 2.4, 95\% Cl 1.1-5.3), 2.4 fold joint and 3.1 fold (OR 3.1, 95\% Cl 1.1-8.4) central nervous system manifestations of BD. Conclusion The PON L55M gene polymorphism seemed to play a role in the pathogenesis of $B D$.

Key words: PON1 gene, Polymorphism, Behçet's disease

Received: 25 June, 2013; revised: 02 April, 2014; accepted: 10 April, 2014; available on-line: 16 June, 2014

\section{INTRODUCTION}

Behçet's disease (BD) is described as a chronic unclassified systemic vasculitis. Although it was originally established with recurrent oral and genital ulcers and uveitis, it is now accepted as a multisystem disorder also affecting all types and sizes of blood vessels, joints, lungs, central nervous system, and intestines (Sakane et al., 1999). In about $20-35 \%$ of cases of BD, diverse vascular complications, such as a deep vein thrombosis, myocardial infarction, arterial aneurysm, and arterial thrombus formation have been diagnosed (Kural-Seyahi et al., 2003). Vascular and cardiac events are partly due to atherosclerosis (Oztürk et al., 2006). In patients with
$\mathrm{BD}$, the mechanism of atherosclerosis may be attributed to lipid abnormalities. Lipids and lipoprotein peroxidation are considered to be important in the pathogenesis of atherosclerosis (Loeper et al., 1983). Their profiles and relation with atherogenesis was described in patients with BD (Orem et al., 1995; Mitamura et al., 1988).

Paraoxonase 1 (PON1) is an enzyme exclusively located on high-density lipoprotein (HDL) in the serum (Ruiz et al., 1995). PON1 hydrolyzes organophosphate substrates and metabolizes lipid peroxides leading to protection against accumulation of low-density lipoprotein (LDL) that otherwise might lead to atherosclerotic plaque formation (Mackness et al., 1997). Major polymorphisms of PON1 include the replacement of Gln (Q) by $\operatorname{Arg}(\mathrm{R})$ at position 192, and that of Leu (L) by Met (M) at position 55. For the L55M PON1 polymorphism, the $\mathrm{L}$ allele carriers were found to have higher mRNA levels (Adkins et al., 1993; Humbert et al., 1993) and accordingly, the $\mathrm{L}$ allele carriers have significantly higher enzyme concentrations (Eckerson et al., 1983). When compared to PON55M isoform, PON55L is associated with higher serum activity, higher stability and resistance to proteolysis. Furthermore PON55L plays an important role in the packing of the protein correctly (Harel et al., 2007). A relationship between PON1 genotypes and the antioxidant activity of HDL has also been demonstrated (Kuremoto et al., 2003).

Functional polymorphisms in the PON1 gene are attractive candidates due to their impact on antioxidant activity of HDL and subsequently on inter-individual vascular disease susceptibility. Common polymorphisms in paraoxonase 1 gene are described as risk factors in a variety of vascular disorders including coronary artery disease and carotid artery stenosis. However, to our knowledge, no investigation has been undertaken on the association between the PON1 L55M single nucleotide polymorphism and BD. In this study, the possible associations between PON1 L55M polymorphism and Turkish BD patients and its clinical manifestations have been investigated.

\section{MATERIALS AND METHOD}

Fifty patients with Behçet's disease and fifty healthy, unrelated control subjects who were all Turkish were included in this study. Patients with Behçet's disease were

\footnotetext{
e-mail: ahmet dursun@hotmail.com
}

Abbreviations: BD, Behçet's disease; PON1, Paraoxonase 1; HDL, high-density lipoprotein; LDL, low-density lipoprotein; ROS, reactive oxygen products 
Table 1. Distribution of the cases and the controls by sex and age, and clinical manifestations of BD

\begin{tabular}{|c|c|c|c|c|}
\hline & Cases n (\%) & & Controls n (\%) & $P$ value \\
\hline Total & $50(100)$ & & $50(100)$ & \\
\hline Age, years mean \pm S.D. & $38.5 \pm 10.16$ & & $36.3 \pm 10.03$ & $p=0.27$ \\
\hline Sex & & & & $p=0.50$ \\
\hline Female & $27(52.0)$ & & $26(54.0)$ & \\
\hline Male & $23(48.0)$ & & $24(46.0)$ & \\
\hline Clinical Manifestation & Positive n (\%) & Negative n (\%) & & \\
\hline Oral Aphthae & $50(100)$ & - & & \\
\hline Genital Ulcers & $47(94)$ & $3(6)$ & & \\
\hline Positive Pathergy test & $23(46)$ & $27(54)$ & & \\
\hline Ocular Manifestations & $16(32)$ & $34(68)$ & & \\
\hline Joint Manifestations & $34(68)$ & $16(32)$ & & \\
\hline Central Nervous System Manifestations & $14(28)$ & $36(72)$ & & \\
\hline Cardiovascular Manifestations & $8(16)$ & $42(84)$ & & \\
\hline Deep Vein Thrombosis & $8(16)$ & $42(84)$ & & \\
\hline Gastrointestinal Manifestations & $19(38)$ & $31(62)$ & & \\
\hline
\end{tabular}

all fulfilling three or more of the International Study Group criteria for BD and were clinically diagnosed by Department of Dermatology. Clinical characteristics of both populations are shown in Table 1.

Genomic DNA was extracted from peripheral blood leucocytes (200 $\mu$ l of total blood) by using MachereyNagel Nucleospin blood ${ }^{\circledR}$ DNA extraction kit (Cat no. 740.951.250) according to manufacturer's instructions. The DNA purity and concentration were determined by spectrophotometric measurement of absorbance at 260 and $280 \mathrm{~nm}$. The PCR product was amplified with primers PON1-F 5'-CCT GCA ATA ATA TGA AAC AAC CTG $3^{\prime}$ and PON1-R 5' TGA AAG ACT TAA ACT GCC AGTC-3'. Amplifications were performed in $0.2 \mathrm{ml}$ thin-wall tubes of $50 \mu \mathrm{l}$ aliquots containing $50 \mathrm{mM} \mathrm{KCl}, 10 \mathrm{mM}$ Tris/HCI, $1.5 \mathrm{mM} \mathrm{MgCl}_{2}, 0.5$ $\mu \mathrm{M}$ of each of the four deoxynucleotides, $50 \mathrm{pmol}$ of each primer (PON1-F and PON1-R), 1 U of Taq DNA polymerase and $20 \mathrm{ng}$ genomic DNA. After an initial 4 min denaturation step at $94^{\circ} \mathrm{C}, 32$ PCR cycles were run, each consisting of: $94^{\circ} \mathrm{C}$ for $1 \mathrm{~min}, 60^{\circ} \mathrm{C}$ for $1 \mathrm{~min}$, and $72^{\circ} \mathrm{C}$ for $1 \mathrm{~min}$. A $72^{\circ} \mathrm{C}$ elongation was performed for $4 \mathrm{~min}$ at end of the PCR cycles. The PCR products of subjects and positive/negative controls were checked on a $1.5 \%$ agarose gel for the assay completion and then the PCR products of 172 bp were digested with restriction enzyme NlaIII by overnight incubation at $37^{\circ} \mathrm{C}$.

NlaIII recognizes the CATG sequence corresponding to the Met allele. The Leu/Leu homozygote was identified by the presence of an uncut $172 \mathrm{bp}$ band, whereas the Leu/Met heterozygote produces all three bands (172, 106 , and $66 \mathrm{bp}$ ) following restriction digestion. The digestion products were electrophoresed on 3.5\% agarose gel and visualized by staining with ethidium bromide and evaluated using a gel documentation system (Syngene, Genegenius Bio Imaging System).

Statistical analysis. A case-control study was performed and allelic frequency of the polymorphism was calculated both in case and control samples. The $\chi^{2}$ test was used to compare allele frequency of the PON55 gene polymorphism between $\mathrm{BD}$ patients and controls.
$95 \%$ confidence interval (CI) was calculated to compare BD risk around genotypes and alleles. $\mathrm{P}$ value less than 0.05 was considered as statistically significant. The software used for the calculations was SPSS version 18 (SPSS Inc., Chicago, IL).

\section{RESULTS}

Age and gender matched 50 subjects with Behçet's disease (26 women and 24 men), and 50 healthy control subjects (27 women and 23 men) were genotyped for the PON55 (rs854560) SNP. The distribution of the genotypes in the controls was in Hardy-Weinberg equilibrium. The mean age ( \pm S.D.) was $38.5 \pm 10.16$ in patients, and $36.3 \pm 10.03$ in control subjects (Table 1 ).

The frequencies of $\mathrm{L}$ and $\mathrm{M}$ alleles were $75.0 \%$ and $25.0 \%$ in cases, and $87.0 \%$ and $13.0 \%$ in controls, respectively (Table 2 ) and the difference in allele frequency was significant $(p=0.04)$. The relative risk for BD patients was more than 2.23 times higher (OR 2.23, 95\% CI 1.07-4.66) in individuals with the PON55 M allele compared to the $\mathrm{L}$ allele.

Also, patients were compared with the control group according to clinical manifestations (Table 3 and 4). Frequency of the $\mathrm{L}$ allele was $65.6 \%, 73.5 \%$, $67.9 \%$ and of the $\mathrm{M}$ allele was $34.4 \%, 26.5 \%, 32.1 \%$ in ocular, joint and central nervous system manifestations of BD patients, respectively. In the ocular, joint and central nervous system manifestations of BD patients, the frequency of the PON55 M allele was higher in comparison with that of the control group and the difference was significant (Table $3, p=0.01, p=0.04$, $p=0.02$, respectively). Compared with the PON55 L allele, the $\mathrm{M}$ allele was associated with greater than 3.5 fold (OR 3.5, 95\% CI 1.3-8.9) increased relative risk of ocular, 2.4 fold (OR 2.4, 95\% CI 1.1-5.3) joint and 3.1 fold (OR 3.1, 95\% CI 1.1-8.4) central nervous system manifestations of $\mathrm{BD}$. The statistical significance was not present when other clinical manifestations of Behçet patients were compared with the control group $(p>0.05)$. 
Table 2. Genotypes and allele frequencies of PON55 and the risk of developing Behçet's disease

\begin{tabular}{|c|c|c|c|c|}
\hline & Cases $(\mathrm{N}=50)$ & Controls $(\mathrm{N}=50)$ & & \\
\hline Variable & n (\%) & n (\%) & $\mathrm{OR} \neq$ & $95 \% \mathrm{Cl}$ \\
\hline \multicolumn{5}{|c|}{ Genotype } \\
\hline LL & $39(62.0)$ & $31(78.0)$ & 1 (reference) & \\
\hline LM & $13(26.0)$ & $9(18.0)$ & 1.817 & $0.688-4.803$ \\
\hline MM & $6(12.0)$ & $2(4.0)$ & 3.774 & $0.712-20.016$ \\
\hline \multicolumn{5}{|l|}{ Allele } \\
\hline L & $75(75.0)$ & 87 (87.0) & 1 (reference) & \\
\hline M & $25(25.0)$ & $13(13.0)$ & 2.23 & $1.07-4.66$ \\
\hline
\end{tabular}

Table 3. The distribution of PON55 genotype frequency in healthy controls and patients according to clinical manifestations.

\begin{tabular}{|c|c|c|c|c|}
\hline & \multicolumn{3}{|c|}{ PON55 Genotype n (\%) } & \multirow{2}{*}{$p$} \\
\hline & LL & LM & MM & \\
\hline Control & $39(78.0)$ & $9(18.0)$ & $2(4.0)$ & \\
\hline Genital Ulcers & $31(66.0)$ & $11(23.4)$ & $5(10.6)$ & 0.3 \\
\hline Positive Pathergy test & $14(60.9)$ & $7(30.4)$ & $2(8.7)$ & 0.3 \\
\hline Ocular Manifestations & $8(50.0)$ & $5(31.3)$ & $3(18.8)$ & 0.07 \\
\hline Joint Manifestations & $20(58.8)$ & $10(29.4)$ & $4(11.8)$ & 0.1 \\
\hline Central Nervous System Manifestations & $7(50.0)$ & $5(35.7)$ & $2(14.3)$ & 0.1 \\
\hline Cardiovascular Manifestations & $4(50.0)$ & $4(50.0)$ & $0(0)$ & 0.1 \\
\hline Deep Vein Thrombosis & $4(50.0)$ & $4(50.0)$ & $0(0)$ & 0.1 \\
\hline Gastrointestinal Manifestations & $11(57.9)$ & $5(26.3)$ & $3(15.8)$ & 0.1 \\
\hline
\end{tabular}

Table 4. Distrubition of the PON55 allele frequency in healthy controls and patients according to clinical manifestations.

\begin{tabular}{|c|c|c|c|c|}
\hline & \multicolumn{2}{|l|}{ PON55 } & \multirow{2}{*}{$\mathrm{P}$} & \multirow{2}{*}{ OR (\% $95 \mathrm{Cl})$} \\
\hline & L ALLELE N (\%) & M ALLELE N (\%) & & \\
\hline Control & $87(87.0)$ & $13(13.0)$ & & \\
\hline Genital Ulcers & $73(77.7)$ & $21(22.3)$ & 0.09 & $1.9(0.9-4.1)$ \\
\hline Positive Pathergy test & $35(76.1)$ & $11(23.9)$ & 0.14 & $2.1(0.8-5.1)$ \\
\hline Ocular Manifestations & $21(65.6)$ & $11(34.4)$ & $0.01^{*}$ & $3.5(1.3-8.9)$ \\
\hline Joint Manifestations & $50(73.5)$ & $18(26.5)$ & $0.04^{*}$ & $2.4(1.1-5.3)$ \\
\hline Central Nervous System Manifestations & $19(67.9)$ & $9(32.1)$ & $0.02^{*}$ & $3.1(1.1-8.4)$ \\
\hline Cardiovascular Manifestations & $12(75.0)$ & $4(25.0)$ & 0.25 & $2.2(0.6-7.9)$ \\
\hline Deep Vein Thrombosis & $12(75.0)$ & $4(25.0)$ & 0.25 & $2.2(0.6-7.9)$ \\
\hline Gastrointestinal Manifestations & $27(71.1)$ & $11(28.9)$ & 0.25 & $2.2(0.6-7.9)$ \\
\hline
\end{tabular}

\section{DISCUSSION}

The etiology and pathogenesis of Behçet's disease (BD) are not yet well understood. Histopathologic studies have established that vasculitis is the predominant lesion, affecting both the vessel wall and perivascular tissues (Sakane et al., 1999). Growing evidence indicates that oxidative stress is increased in $\mathrm{BD}$, relating to overproduction of reactive oxygen products (ROS) and decreased efficiency of antioxidant resistance (Kose et al., 1951; Orem et al., 1997; Niwa et al., 1982). It has been demonstrated in in vitro studies that activated leucocytes form a large number of free oxygen radicals and this in turn causes endothelial cell damage. ROS can attack and damage a variety of critical biological molecules, includ- ing lipids, essential cellular proteins and DNA. Under oxidative stress, LDL and other serum lipoproteins, including HDL, are prone to lipid peroxidation. Recent studies show that lipid peroxidation in the serum of patients with BD was increased (Kose et al., 1951; Orem et al., 1997; Kose et al., 2001).

PON-1 is a serum enzyme bound with high density lipoproteins (HDL) and has been closely linked to the control of oxidative stress and inflammation, mainly at the circulation level $(\mathrm{NgD}$ et al., 2008). PON 1 protects lipoproteins against oxidative stress and makes possible to metabolize lipid peroxides that are largely distributed among tissues such as the liver, kidney, and intestine; but it is also present in plasma. There is a 10- to 40 -fold inter-individual variability in serum PON1 activity (Hum- 
bert et al., 1993). PON1 gene polymorphism is one of the sources of this variability. When compared to PON1$55 \mathrm{M}$ allele, PON1-55L is correlated with higher PON1 activity and mRNA levels (Leviev et al., 1997; Li et al., 2000; Leviev et al., 2001). Karakucuk and coworkers (2004) and Mungan (2006) and coworkers found a decreased serum PON1 activity in BD patients in comparison with healthy controls. Decreased PON1 could explain the increased lipid peroxidation and oxidative stress observed in BD. This suggests a pathogenic mechanism that is supported by our study, where we show a significant correlation between the PON1 gene polymorphism and BD patients. Our study shows that carriers of the PON1 M allele have a 2.23 fold increased relative risk for developing BD. To our knowledge, this is the first study that investigates the possible associations between PON 55 polymorphism with Behçet's patients in a Turkish population.

PON1 is an HDL-associated enzyme which is able to hydrolyze organophosphates. Due to its functions in protecting LDL against oxidation, PON1 is also an antioxidant. Decrease in the levels of paraoxonase enzyme is a great risk for patients with cardiovascular diseases, rheumatoid arthritis, gout, and age-related macular degeneration (Ekinci et al., 2009; Jiang et al., 2011). Karakucuk et al. also found a decreased serum PON1 activity in BD patients with ocular involvement in comparison with healthy controls. PON is also important in metabolism as an organophosphate hydrolyser. Thus, PON1 protects the nervous system against organophosphate toxicity. Therefore, when patients with ocular, joint and central nervous system involvement were compared to the control group, this statistical significance was getting sharper.

Although the result of this study is statistically significant, because of the rarity of the Behçet's disease the sample size is considered as a limitation. In addition, further studies with different ethnic populations should be performed to validate whether there is a relationship between Behcet's disease and PON1 L55M gene polymorphisms.

Our findings suggest that PON1 L55M polymorphism is associated with an increased relative risk for BD. This finding was getting sharper when ocular, joint and central nervous system involvement was considered separately. Polymorphism in the PON1 gene might contribute to the reduced PON activity that causes increased lipid peroxidation and oxidative stress and inflammatory endothelial changes observed in patients with BD.

\section{REFERENCES}

Abuja PM, Albertini R, Esterbauer H (1997) Simulation of the induction of oxidation of low-density lipoprotein by high copper concentrations: evidence for a nonconstant rate of initiation. Chem Res Toxicol 10: 644-651.

Adamson DC, Wildemann B, Sasaki M, Glass JD, McArthur JC, Christov VI, Dawson TM, Dawson VL (1996) Immunologic NO synthase: elevation in severe AIDS dementia and induction by HIV-1 gp41. Science 274: 1917-1921.

Adkins S, Gan KN, Mody M, et al (1993). Molecular basis for the polymorphic forms of human serum paraoxonase/arylesterase: glutamine or arginine at position 191, for the respective A or B allozymes. Am J Hum Genet 52: 598-608.

Eckerson HW, Wyte CM, La Du BN (1983). The human serum paraoxonase/ arylesterase polymorphism. Am J Hum Genet 35: 1126-38.

Ekinci D, Beydemir S (2009) Evaluation of the impacts of antibiotic drugs on PON 1; a major bioscavenger against cardiovascular diseases. Eur J Pharmacol 617: 84-89.
Freitas JP, Filipe P, Yousefi A, Emerit I, Guerra Rodrigo F (1998) Oxidative stress in Adamantiades-Behcet's disease. Dermatology 197: 343-348.

Harel M, Brumshtein B, Meged R, Dvir H, Ravelli RB, McCarthy A, et al (2007). 3-D structure of serum paraoxonase 1 sheds light on its activity, stability, solubility and crystallizability. Arb Hig Rada Toksikol 58: $347-353$.

Humbert R, Adler DA, Disteche CM, et al (1993). The molecular basis of the human serum paraoxonase activity polymorphism. Nat Genet 3: 73-76.

Jiang XL, Li M, Zhou JG, Yang QB, Du LJ, Du J (2011). Plasma paraoxonase-1, oxidized low-density lipoprotein and lipid peroxidation levels in gout patients. Cell Biochem Biophys. 61: 461-466.

Karakucuk S, Baskol G, Oner AO, Baskol M, Mirza E, Ustdal M (2004) Serum paraoxonase activity is decreased in the active stage of Behçet's disease. Br J Ophthalmol 88: 1256-1258.

Kose K, Dogan P, Ascioglu M, Erkilic K, Ascioglu O (1951) Oxidative stress and antioxidant defenses in plasma of patients with Behcet's disease. Tohoku J Exp Med 76: 239-248.

Kose K, Yazici C, Assioglu O (2001) The evaluation of lipid peroxidation and adenosine deaminase activity in patients with Behcet's disease. Clin Biochem 34: 125-129.

Kural-Seyahi E, Fresko I, Seyahi N, Ozyazgan Y, Mat C, Hamuryudan $\mathrm{V}$ et al. (2003) The long-term mortality and morbidity of Behcet syndrome: a 2-decade outcome survey of 387 patients followed at a dedicated center Medicine (Baltimore) 82: 60-76.

Kuremoto K, Watanabe Y, Ohmura H, Shimada K, Mokuno H, Daida $\mathrm{H}$ (2003) R/R genotype of human paraoxonase (PON1) is more protective against lipoprotein oxidation and coronary artery disease in Japanese subjects. J Atheroscler Thromb 10: 85-92.

Leviev I, Deakin S, James RW (2001) Decreased stability of the M54 isoform of paraoxonase as a contributory factor to variations in human serum paraoxonase concentrations. J Lipid Res 42: 528-535.

Leviev I, Negro F, James RW (1997) Two alleles of the human paraoxonase gene produce different amounts of mRNA. An explanation for differences in serum concentrations of paraoxonase associated with the (Leu-Met54) polymorphism. Arterioscler Thromb Vasc Biol 17: 2935-2939.

Li WF, Costa LG, Richter RJ, Hagen T, Shih DM, Tward A, Lusis AJ, Furlong CE (2000) Catalytic efficiency determines the in-vivo efficacy of PON1 for detoxifying organophosphorus compounds. Pharmacogenetics 10: 767-79.

Loeper J, Ement J, Goy J, et al (1983) Lipid peroxidation during human atherosclerosis. IRCS Med Sci 11: 1035-43.

Mackness B, Mackness MI, Arrol S, Turkie W, Durrington PN (1997). Effect of the molecular polymorphisms of human paraoxonase (PON1) on the rate of hydrolysis of paraoxon. Br J Pharmacol 122: 265-268.

Mitamura T, Ohmo S, Ariga H, et al (1988) Lipoprotein cholesterol concentrations in patients with Behcet's disease. Clin Chim Acta 175: $277-284$.

Mungan AG, Can M, Açikgöz S, Eştürk E, Altinyazar C (2006) Lipid peroxidation and homocysteine levels in Behçet's disease. Clin Chem Lab Med 44: 1115-1118.

NgD S, ChuT, Esposito B, et al (2008) Paraoxonase-1 deficiency in mice predisposes to vascular inflammation, oxidative stress, and thrombogenicity in the absence of hyperlipidemia. Cardiovasc Pathol 17: 226-322.

Niwa Y, Miyake S, Sakane T, Shingu M, Yokoyama M (1982). Autooxidative damage in Behcet's disease: endothelial cell damage following the elevated oxygen radicals generated by stimulated neutrophils. Clin Exp Immunol 49: 247-255.

Orem A, Efe H, Deger O, Cimsit G, Uydu HA, Vanizor B (1997) Relationship between lipid peroxidation and disease activity in patients with Behcet's disease. Dermatol Sci 16: 11-16.

Orem A, Deger O, Cimsit G, et al (1995) Plasma lipoprotein (a) and its relationship with disease activity in patients with Behçet's disease. Eur J Clin Chem Clin Biochem 33: 473-478.

Orem A, Deger O, Memis O, et al (1995) Lp(a) lipoprotein levels as a predictor of risk for thrombogenic events in patients with Behçet's disease. Ann Rheum Dis 54: 726-729.

Oztürk MA, Oktar SO, Unverdi S, Ureten K, Göker B, Haznedaroğlu $\mathrm{S}$, et al.(2006) Morphologic evidence of subclinical atherosclerosis obtained by carotid ultrasonography in patients with Behçet's disease. Rheumatol Int 26: 867-872.

Ruiz J, Blanche H, James RW, Garin MC, Vaisse C, Charpentier G, Cohen N, Morabia A, Passa P, Froguel P (1995). Gln-Arg192 polymorphism of paraoxonase and coronary heart disease in type 2 diabetes. Lancet 346: 869-872.

Sakane T, Takeno M, Suzuki N, and Inaba G (1999) Behçet's disease. The New England Journal of Medicine 341: 1284-1291. 